\title{
EFFECT OF TANK GEOMETRIC SHAPE RATIO ON PRODUCTIVITY OF RECIRCULATING AQUACULTURAL SYSTEM
}

\author{
Ahmed M. Ragab ${ }^{1}$, Abdel Ghany M. El-Gindy ${ }^{2}$, Yasser E. Arafa ${ }^{3}$ and
} Ashraf Y. EL Dakar ${ }^{4}$

\begin{abstract}
The main aim of this work is to study the effect of tank diameter depth ratio on the water quality and productivity of recirculating aquacultural system to reach the optimum tank diameter: water depth ratio. The obtained results indicated that the mean weight of fish increased from 18 to 148,18 to 136 and 18 to $114 \mathrm{~g}$ after 14 weeks with the diameter depth ratios 4, 6.4 and 8, respectively. The average weight gain of fish increased from 2 to 21, 8 to 13 and 3 to $6 \mathrm{~g}$ after 14 weeks with the diameter depth ratios 4, 6.4 and 3, respectively. The specific growth rate ranged from 0.99 to $6.00,0.39$ to 5.25 and 0.17 to $5.10 \%$ day $^{-1}$ at $4,6.4$ and 8 diameter depth ratio. The feed conversion rate ranged from 0.68 to 3.53, 0.88 to 10.91 and 0.93 to $18.51 \mathrm{~kg}$ feed $/ \mathrm{kg}$ fish at 4, 6.4 and 8 diameter depth ratio. The feed efficiency ranged from 0.28 to $1.46,0.11$ to 1.13 and 0.05 to 1.39 at 4, 6.4 and 8 diameter depth ratio. The mean daily mortality rates were 0.048, 0.058 and $0.064 \%$ at 4, 6.4 and 8 diameter depth ratio, respectively.
\end{abstract}

Keywords: circular tank, Tank geometry, Recirculating Aquaculture, Fish, Productivity

\section{INTRODUCTION}

$\mathrm{F}$ lish production in an intensive recirculating aquaculture system (RAS) has the potential to achieve considerable savings in water and land: it requires less than $10 \%$ of the water needed by extensive ponds to produce a given quantity of fish (Hamlin et al., 2008). In recirculating culture systems, water exiting the culture units undergoes some form of treatment to improve its quality and is then recycled back into the system (Appleford et al., 2003).

\footnotetext{
${ }^{1}$ Demonstrator Aquac., Eng., Fac. Fish Resources, Suez Univ., Egypt

${ }^{2}$ Prof. of Agric. Eng., Fac. of Agric., Ain Shams Univ., Egypt

${ }^{3}$ Ass. Prof. of Agric. Eng., Fac. of Agric., Ain Shams Univ., Egypt

${ }^{4}$ Prof. of Aquac., Fac. Fish Resources, Suez Univ., Egypt
} 
Water parameters requiring regulation include particulate matter resulting from unconsumed feed and feces, nitrogenous wastes, dissolved gases, pathogens, pH and alkalinity (Lin et al., 2005).

One of the main challenges for sustainable aquaculture is the rational use of resources, mainly water and space. To fulfil this aim, aquaculture production units should be designed to use a minimum rearing volume in which fish can be kept under the best conditions for growth, ensuring fish welfare and minimum resource consumption. These can be achieved when a tank provides uniformity of rearing conditions, favouring a homogeneous fish distribution that consequently guarantees optimal use of the entire rearing volume (Duarte et al., 2011).

Tanks used for intensive fish culture are of varied shape and flow pattern (Wheaton, 1977; Piper et al., 1982; Klapsis and Burley, 1984; Cripps and Poxton, 1992). Tanks are designed with considerations for production cost, space utilization, water quality maintenance, and fish management. There is a definite trend towards large circular culture tanks for food fish production. Tanks more than $10 \mathrm{~m}$ in diameter, which used to be referred to as pools, are now reasonable choices for culture systems in intensive indoor operations. Circular tanks are attractive for the following reasons: simple to maintain, provide uniform water quality, allow operating over a wide range of rotational velocities to optimize fish health/condition, settleable solids can be rapidly flushed through the center drain and permit designs that allow for visual or automatic observation of waste feed to enable satiation feeding (Timmons et al., 1998).

The production of food fish in large circular tanks has produced large cost savings in comparison to raising the same quantity of fish in more but smaller tanks. Larger circular culture tanks offer many advantages for food fish production. While just a few years ago, an $8 \mathrm{~m}$ diameter tank was considered large, now we are seeing 10 and $15 \mathrm{~m}$ and even larger diameter tanks being put into production. Substantial savings in both capital and labor costs can be realized by shifting production into fewer but larger culture tanks. Fundamentally, the time it takes to service a small tank or a large tank is similar. In fact, the capital costs associated 
with large versus small is not proportional to tank volume. Dramatic cost savings can be obtained by using larger and larger tanks. Circular tanks make good culture vessels for the following reasons: Improves the uniformity of the culture environment, allow a wide range of rotational velocities to optimize fish health and condition and rapid concentration and removal of settleable solids (Timmons et al., 2010).

Tank design which is adapted to the way certain species behave and swim can aid in reducing stress levels and improving fish welfare, which in turn contributes to enhancing fish growth (Palstra and Planas, 2011). Moreover, homogeneous water quality makes it possible to take further advantage of the entire rearing volume, the water flow and the oxygen added to the water. This ensures that all areas of the tank provide optimum rearing conditions (Ross et al., 1995).

Recommended tank diameter to depth ratios vary from $5: 1$ to $10: 1$ (Chenoweth et al. 1973; Larmoyeux et al. 1973); even so, many farms use tanks with diameter: depth ratios as low as 3:1. Selection of a tank diameter: depth ratio is also influenced by factors such as the cost of floor space, water head, fish stocking density, fish species, and fish feeding levels and methods. Choices of depth should also consider ease of workers handling fish within the tank and safety issues of working in waters that may be more than "chest" high.

In the early years of RAS, tanks that were actually deeper than their diameter were touted as a key design factor to economic success. None of these systems were successful, mostly for problems related to fish management. Even in more modest attempts to utilize deeper tanks, e.g., a 3:1 ratio of diameter: depth, not all fish will effectively distribute into the entire water column. Therefore, the main aim of this work is to study the effect of tank diameter depth ratio on the water quality and productivity of recirculating aquacultural system to reach the optimum tank diameter: water depth ratio.

\section{MATERIALS AND METHODS}

The experiment was carried out at a private farm which is located in ElNenaiea, Ashmon, El-Minufiya Governorate, Egypt during of 2015 season. 


\subsection{Materials}

\subsubsection{System Description:}

Figure (1) illustrates the experimental setup. It shows the recirculating aquaculture system (RAS) which consists of fish tank, hydrocyclone, screen filter, biological filter and oxygen contactor.

The system consists of three tanks are a circular in shape made of concrete which were used for fish culture. The three tanks are identical in depth $(1.35 \mathrm{~m})$, but different in size and capacity, which were 24.5, 62.8 and $98.1 \mathrm{~m}^{3}$ (5.0, 8.0 and $10.0 \mathrm{~m}$ diameter), respectively. Each tank was provide to a particle trap in the center set in the concrete tank foundation (floor) for water drain waste solids. The trap was provided with double drainage, one of them for the settleable solids and the other for the suspended solids. The first opening allows for $1-10 \%$ of the total flow leaving the tank. The second opening allows of $90-99 \%$ of the total flow to leave the tank. The waste particles settle and are retained in the sludge collector and the clarified water exits the sludge collector at the top and flows by gravity for further treatment. The level of water was controlled by standpipe.

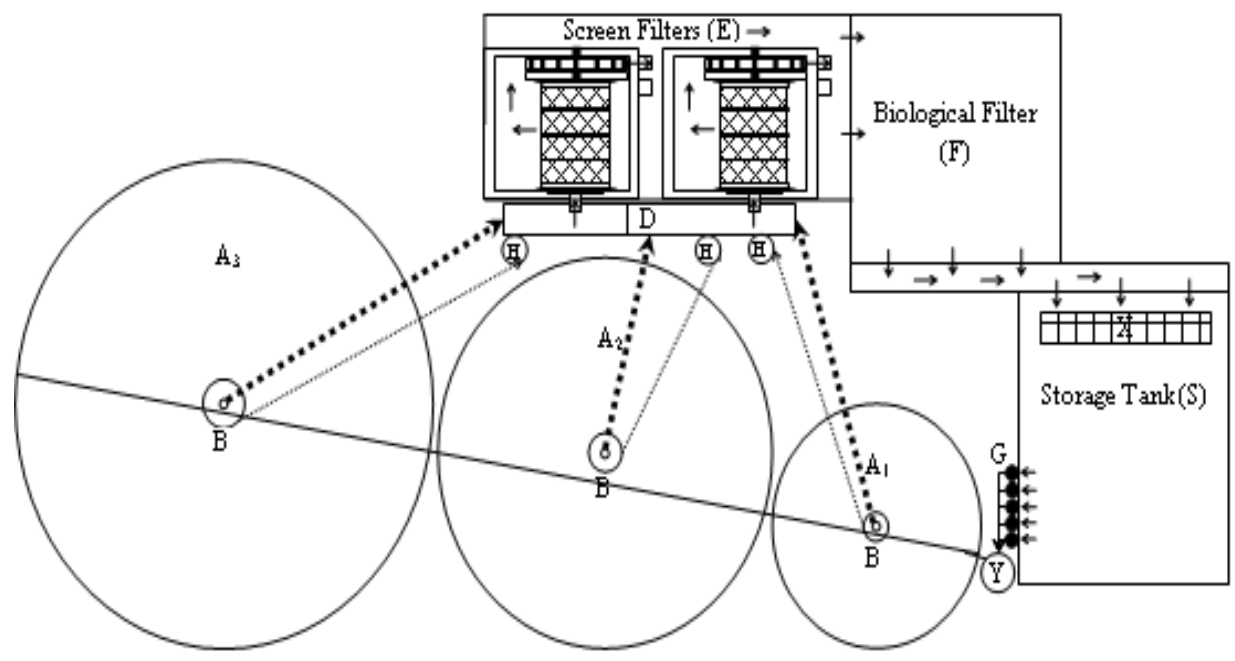

Figure (1): Schematic diagram of the recirculating aquaculture system (RAS). Fish tank, A; particle trap, B; hydro cyclone $\mathrm{H}$; channel collector, D; screen filter, E; biological filter, F; storage tank, S; pumps, G; heat exchanger, $\mathrm{X}$; down flow oxygen contactor, $\mathrm{Y}$. 
The sludge collector is used to remove the settleable solids. It is made of stainless steel and has inlet diameter of $50 \mathrm{~mm}$, overflow diameter of 50 $\mathrm{mm}$, height of $800 \mathrm{~mm}$, top diameter of $335 \mathrm{~mm}$, underflow diameter of $50 \mathrm{~mm}$ and cone angle of $68^{\circ}$.

The system consists of two drum screen filter. The drum screen filter is used to remove the suspended solids and has dimensions of $1.35 \mathrm{~m}$ in diameter and $1.85 \mathrm{~m}$ long. The water enters the open end of a drum filter and passes through a screen attached to the outer surface of the filter. The filter was made from stainless steel manufactured at a private company for steel industry. The fine mesh (silk 100 micron) was used as a media of screening. The filters were driven by undershot waterwheel to give the recommended rotating speed (3 - $6 \mathrm{rpm}$ ) (Libey, 1993). The drum rotates and the solids retained on the screen are removed in a section by backflushing with the previously filtered water. A separate launder takes the back-flush suspension off for further processing.

Rotating Biological Contactor (RBC) was used in this system, approximately 40 percent of the substrate is submerged in the recycle water. The filter dimensions were $1.5 \mathrm{~m}$ in diameter and $2.0 \mathrm{~m}$ long. The filter was made from stainless steel. Plastic sheets were used as a media. The filter was driven by one motor of $1.5 \mathrm{hp}$ power and $1500 \mathrm{rpm}$ and controlled by a gearbox of reduction ratio of 500 to give the recommended rotation speed (3 rpm) (Ali et al., 2006). Adding pure oxygen gas to water by oxygen mixer. The water and oxygen enter the top of the oxygen mixer, as the water and oxygen move downward.

\subsection{Methods:}

Tilapia nilotica fingerlings, which were used in the experiment, were brought from the General Authority for Fish Resources Development of A.R.E. in El-Knater El-Khiria, Kalubia, Eygpt. The fish was weighed every week and the flow rate was adjusted according to the growth rate. The weekly fish weight was used to adjust both of water flow rate and oxygen flow rate.

Water used throughout experimentation was derived from well. Total ammonia nitrogen (TAN) and nitrite were below the limits of detection. Dissolved oxygen was $1.5 \mathrm{mg} / \mathrm{L}$. The $\mathrm{pH}$ was 7.5 . 
The daily feed rates at different fish sizes were applied according to Rakocy (1989) and the feed pellet diameter was prepared according to Jauncey and Ross (1982). Feeding was stopped during weighing process.

\subsubsection{Growth performance parameters:}

The growth performance parameters are calculated according to the following equations:

- Average Weight Gain (AWG): -

(AWG) $=$ Average final weight $(\mathrm{g})-$ Average initial weight $(\mathrm{g})$

- Specific Growth Rate (SGR \%/day): -

$($ SGR \% / day $)=100[\mathrm{Ln} \mathrm{Wt1}-\mathrm{Ln} \mathrm{Wt} 0 / \mathrm{t}]$

Where:
Ln: normal log
Wt 0: initial weight $(\mathrm{g})$.
Wt 1: final weight $(\mathrm{g})$
T: time of days.

\subsubsection{Feed and protein utilization parameters:}

Feed and protein utilization parameters are calculated according to the following equations:

- Feed Conversion Ratio (FCR):

$\mathbf{F C R}=$ Total feed consumption/ weight gain

- Feed efficiency (FE):

$\mathbf{F E}=$ weight gain / Total feed consumption

\section{RESULTS AND DISCUSSION}

\subsection{Mean weight of fish:}

Figure (2) shows the mean weight of fish as affected by diameter depth ratio (4, 6.4 and 8) during the production period (week). It could be seen that the mean weight of fish increased from 18 to 40 (by 55.0\%), 18 to 36 (by $50.0 \%$ ) and 18 to 33 (by $45.5 \%$ ) g after 5 weeks with the diameter 
depth ratios 4, 6.4 and 8, respectively. Whereas, after 10 weeks, the mean weight of fish increased by $78.8,75.7$ and $78.0 \%$ for $4,6.4$ and 8 diameter depth ratios, respectively. At the end of production period (14 weeks) the mean weights of fish increased by $87.8,86.8$ and $84.2 \%$ for the same pervious order it indicated that the low diameter depth ratio recorded the highest increasing percentage $(87.8 \%)$ at 14 weeks. While, the predicted weight of fish increased 59.1, 82.0 and $88.8 \%$ after 5, 10 14 weeks during the growth period, respectively.

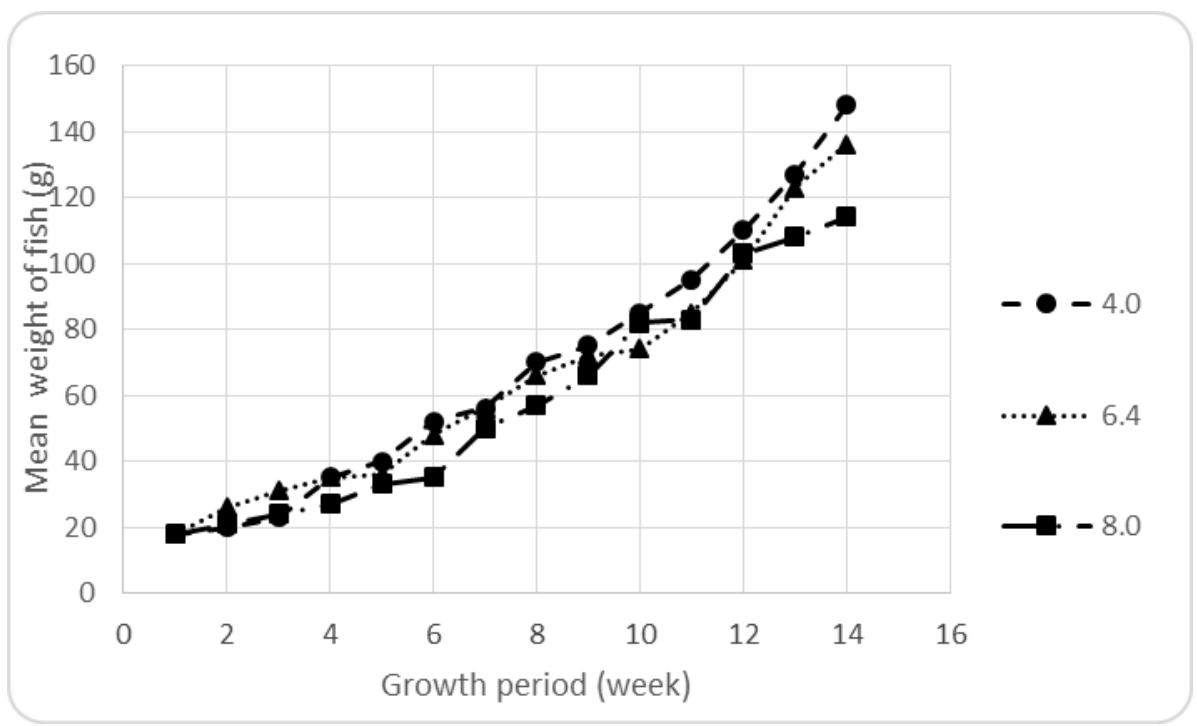

Figure (2): Effect of Geometric shape (diameter:depth) ratio on mean weight of fish.

\subsection{Average weight gain:}

Figure (3) shows the average weight gain as affected by diameter: depth ratio (4, 6.4 and 8 ) during the growth period (week). The results that the average weight gain increased from 2 to 21 (by $90.5 \%$ ), 8 to 13 (by 38.5 $\%$ ) and 3 to 6 (by $50.0 \%$ ) g per week at the end of growth period with the diameter depth ratios 4, 6.4 and 8 , respectively. The results also show the low diameter depth ratio recorded the highest increasing percentage $(90.5 \%)$ at the end of growth period. While, the predicted average weight gain increased from 5 to 18 (by $72.2 \%$ ) g per week at the end of growth period. The results of this study were similar to those reported by 
Rodrigo and Olivares (2004), under recirculating systems (WG $=0.5$ $3 \mathrm{~g} \mathrm{day}^{-1}$ ) and Imsland et al. (1996) in flow - through systems (WG $=0.5$ $-3.5 \mathrm{~g} \mathrm{day}^{-1}$ ). The predicted weight gain increased 5 to $18 \mathrm{~g}$ per week (by $72.2 \%$ ) at the end of growth period.

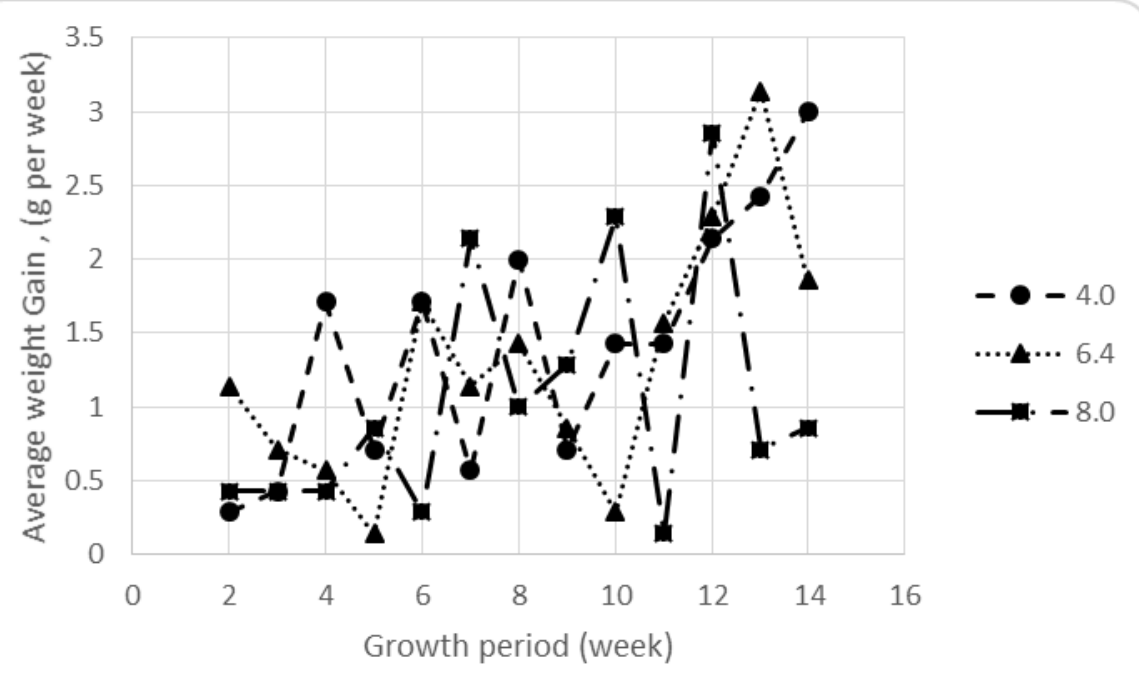

Figure (3): Effect of Geometric shape (diameter:depth) ratio on average weight gain.

\subsection{Specific growth rate:}

The specific growth rate is indictor of the average weight gained of the fish at a certain times. Figure (4) shows the effect of diameter depth ratio on the specific growth rate. The results showed that the specific growth rate ranged from 0.99 to $6.00,0.39$ to 5.25 and 0.17 to $5.10 \%$ day $^{-1}$ at 4 , 6.4 and 8 diameter depth ratio. This results were almost the same as those reported by Poxton et al. (1982) under recirculating systems (SGR=1 $1.8 \%$ ), Imsland et al. (1996) in flow -through systems ( $\mathrm{SGR}=1.4-2.7$ $\%)$ and Rodrigo and Olivares (2004) in flow -through system, the overall SGR was $1.4 \%$, ranging from 0.5 to $2.5 \%$. The predicted specific growth rate ranged from 1.76 to $3.50 \%$ day $^{-1}$.

\subsection{Feed conversion ratio:}

Figure (5) shows the effect of diameter depth ratio on the feed conversion rate ( $\mathrm{kg}$ feed/ $\mathrm{kg}$ added to the fish weight). The results showed that the 
feed conversion rate ranged from 0.68 to $3.53,0.88$ to 10.91 and 0.93 to $18.51 \mathrm{~kg}$ feed/kg fish at 4, 6.4 and 8 diameter depth ratio. The predicted feed conversion rate ranged from 1.38 to $1.64 \mathrm{~kg}$ feed $/ \mathrm{kg}$ fish. These results were in agreement with those obtained by (Labatut, 2001).

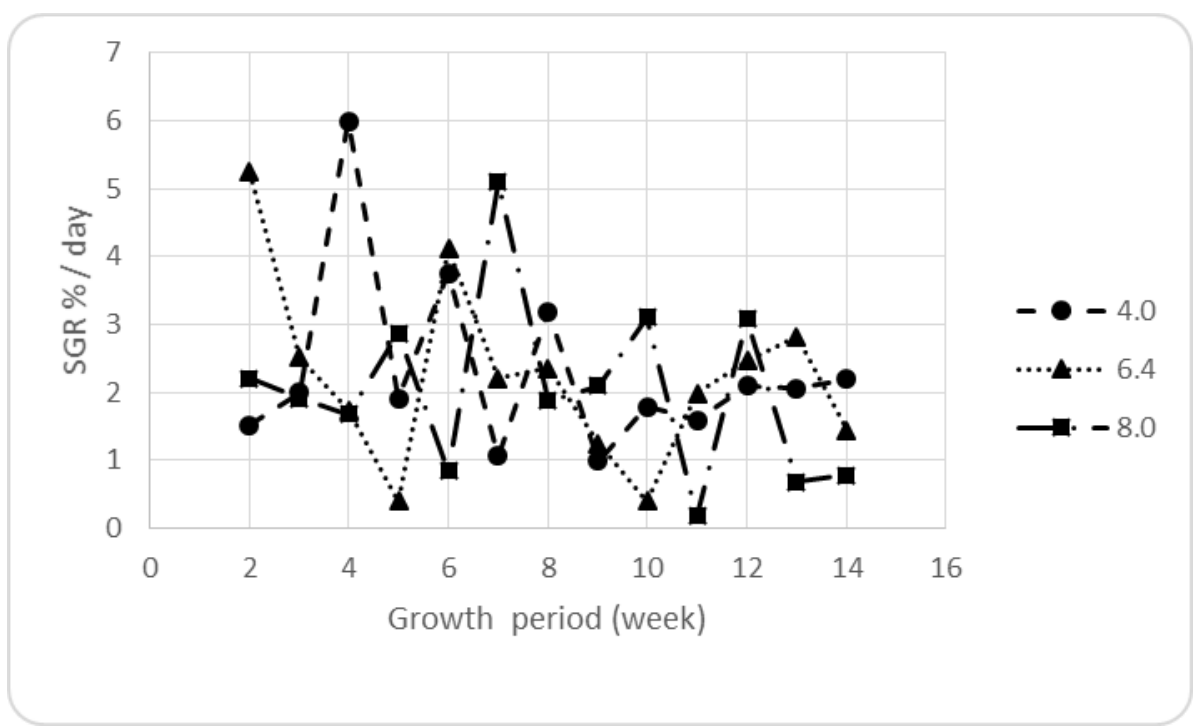

Figure (4): Effect Geometric shape (diameter:depth) ratio on specific growth rate.

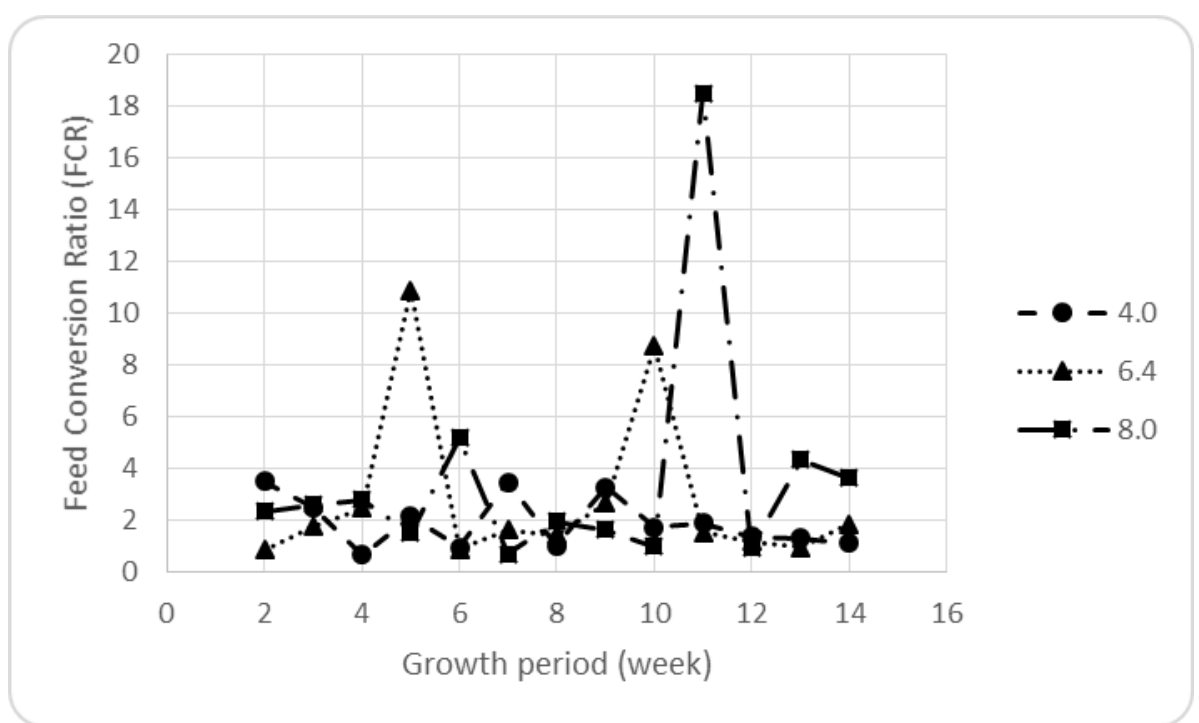

Figure (5): Effect of Geometric shape (diameter:depth) ratio on feed conversion rate. 


\subsection{Feed efficiency:}

Figure (6) shows the effect of diameter depth ratio on the feed efficiency. The results showed that the feed efficiency ranged from 0.28 to 1.46, 0.11 to 1.13 and 0.05 to 1.39 at $4,6.4$ and 8 diameter depth ratio. The predicted feed efficiency ranged from 0.61 to 0.72 .

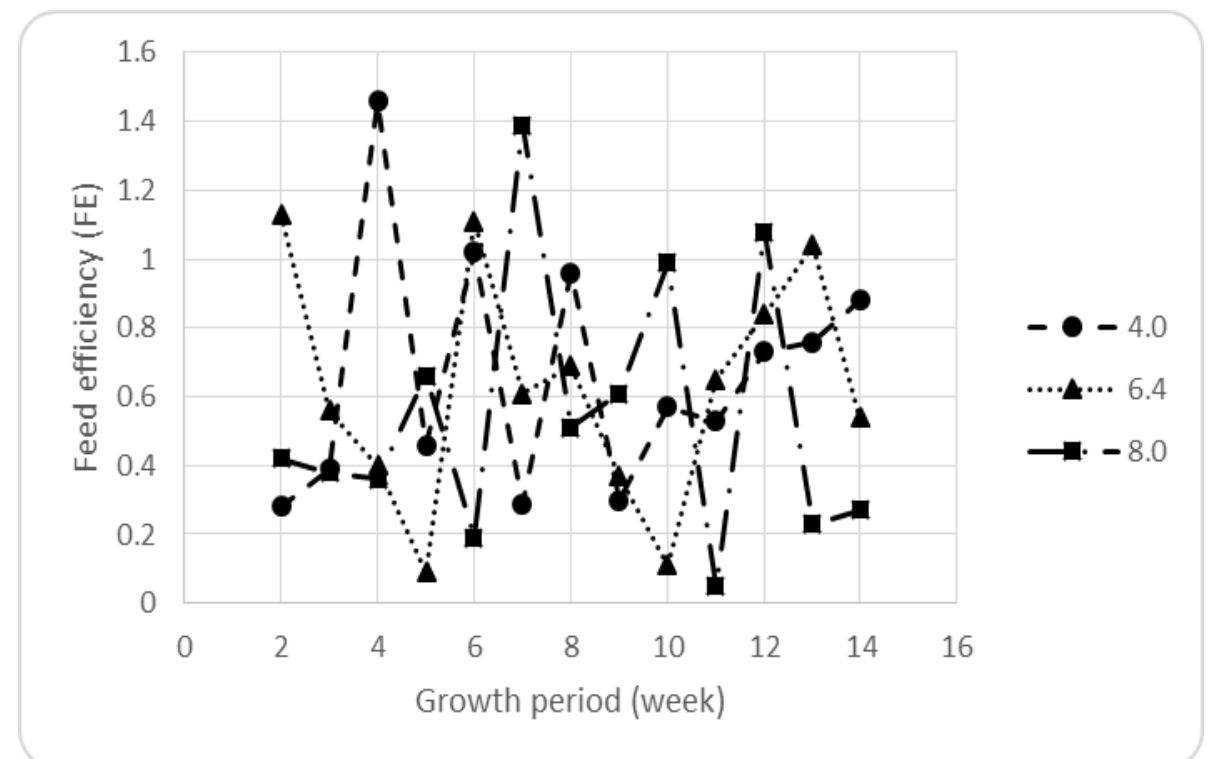

Figure (6): Effect of Geometric shape (diameter:depth) ratio on feed efficiency.

The results showed that the daily mortality rate ranged from 0.00 to $0.083,0.019$ to 0.075 and 0.020 to $0.080 \%$ at $4,6.4$ and 8 diameter depth ratio. While, the mean daily mortality rates were $0.048,0.058$ and 0.064 $\%$ at $4,6.4$ and 8 diameter depth ratio, respectively. The lowest value of daily mortality rate $(0.048 \%)$ was found at 4 diameter depth ratio and the highest value of daily mortality rate $(0.064 \%)$ was found at 8 diameter depth ratio. These results were in agreement with those obtained by (Rodrigo and Olivares, 2004) who's found the daily mortality rate was ranged from 0.0 to 0.035 . 


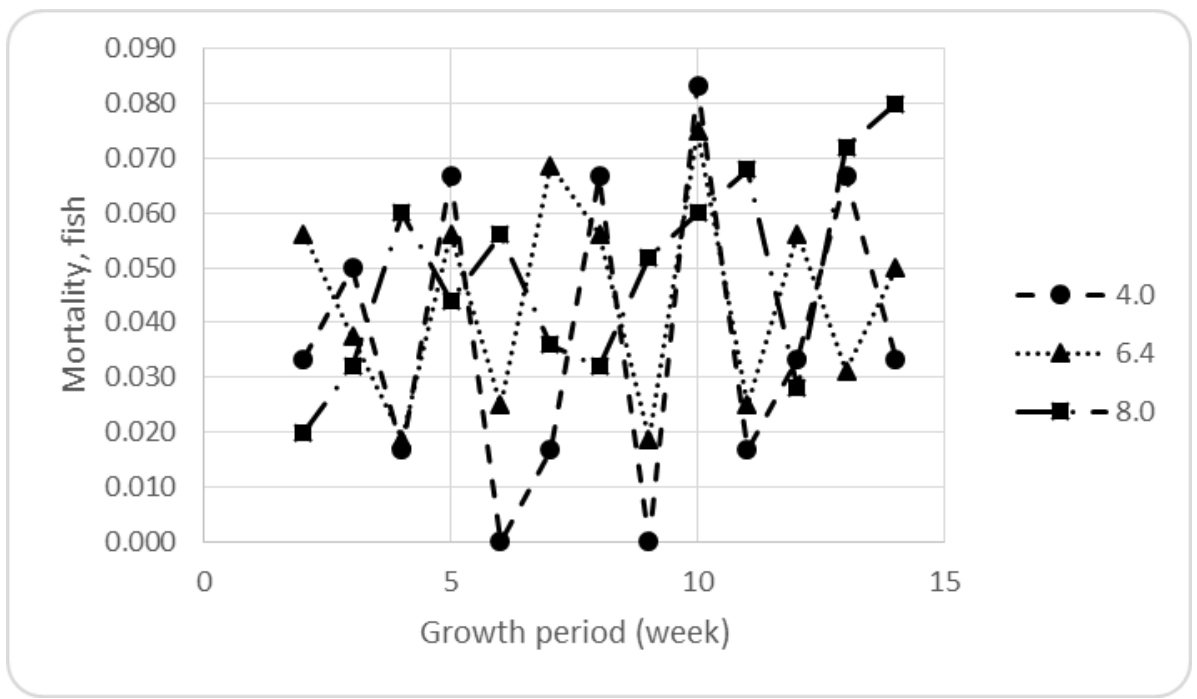

Figure (7): Effect of Geometric shape (diameter:depth) ratio on daily mortality rate.

\section{CONCLUSION}

The experiment was carried out to study is to the effect of tank diameter depth ratio on the water quality and productivity of recirculating aquacultural system to reach the optimum tank diameter: water depth ratio. The obtained results can be summarized as follows:

- The mean weight of fish increased from 18 to 148,18 to 136 and 18 to $114 \mathrm{~g}$ after 14 weeks with the diameter depth ratios 4.0, 6.4 and 8.0 , respectively.

- The average weight gain of fish increased from 2 to 21,8 to 13 and 3 to $6 \mathrm{~g}$ after 14 weeks with the diameter depth ratios 4.0, 6.4 and ^.0, respectively.

- The average of specific growth rate was 2.29, 2.20 and 2.01 at 4.0, 6.4 and 8.0 diameter depth ratio, respectively during the experiment period.

- The average of feed conversion rate was $1.70,1.83$ and $2.10 \mathrm{~kg}$ feed/kg fish at 4.0, 6.4 and 8.0 diameter depth ratio, respectively during the experiment period.

- The average of feed efficiency was $0.59,0.55$ and $0.48 \mathrm{~kg}$ fish $/ \mathrm{kg}$ feed at 4.0, 6.4 and 8.0 diameter depth ratio, respectively during the experiment period. 
- The mean daily mortality rates were $0.048,0.058$ and $0.064 \%$ at 4.0 , 6.4 and 8.0 diameter depth ratio, respectively during the experiment period.

\section{REFERENCES}

Ali, S.A., El-Haddad, Z.A., AND Gharieb, A. (2006). Design of a Rotating Biological Contactor in a Recirculating Aquaculture System. Misr J. Ag. Eng., 23(2): 396-408.

Appleford, P., J. S. Lucas and P. C. Southgate (2003). General principles. In: Lucas, J. S. and P. C. Southgate, (Eds.). Aquaculture: Farming Aquatic Animals and Plants. Blackwell Publishing, Oxford, England. P. 11-46.

Chenoweth, H.H., Larmoyeux, J.D., Piper, R.G. (1973). Evaluation of circular tanks for salmonid production. Prog. Fish-Cult., 35:122131.

Cripps, S. J., Poxton, M. G. (1992). A review of the design and perform of tanks relevant to flatfish culture. Aquacultural Engineering, 11: pp 71-91.

Duarte, S., Reig, L., Masaló, I., Blanco, M., Oca, J. (2011). Influence of tank geometry and flow pattern in fish distribution. Aquacultural Engineering, 44: 48-54.

Hamlin, H.J., Michaels, J.T., Beaulaton, C.M., Graham, W.F., Dutt, W., Steinbach, P., Losordo, T.M., Schrader, K.K., Main, K.L. (2008). Comparing denitrification rates and carbon sources in commercial scale upflow denitrification biological filters in aquaculture. Aquacultural Engineering, 38:79-92.

Imsland, A. Ksunde., L. M. Folvord, A. and Stefansson, S. O. (1996). The interaction of temperature and fish size on growth of juvenile turbot. J. Fish Biol., 49: 926-940.

Jauncey, K. and Ross, B. (1982). A guide to tilapia feeds and feeding. Institute of aquaculture, university of sterling, Scotland. $111 \mathrm{pp}$.

Klapsis, A., Burley, R. (1984). Flow distribution studies in fish rearing tanks. Part 1, Design constraints. Aquacultural Engineering, 3:pp 103-118.

Labatut, R. A. (2001). Aplicacion de ozono en un sisttema de recirculacion para el cultivo de juveniles de turbot, Scophthalmus 
maximus en shallow raceways. Memoria de titulo, Universidad Catolica del, Coquimbo, Chile, pp. 113.

Larmoyeux, J.D., Piper, R.G., Chenoweth, H.H. (1973). Evaluation of circular tanks for salmonid production. The Progressive FishCulturist, 35(3):p 122-131.

Libey, G.S. (1993). Evaluation of a drum filter for removal of solids from a recirculating aquaculture system. In: J.K. Wang (Ed.), Techniques for modem aquaculture. St. Joseph, Ml, American Society of Agricultural Engineers, pp. 519-532.

Lin, Y.F., Jing, S.R., Lee, D.Y., Chang, Y.F., Chen, Y.M., Shih, K.C. (2005). Performance of a constructed wetland treating intensive shrimp aquaculture wastewater under high hydraulic loading rate. Environ. Pollut., 134 (3):411-421.

Palstra, A.P., Planas, J.V. (2011). Fish under exercise. Fish Physiology and Biochemistry, 37:259-272.

Piper, R.E., McElwain, LB., Orme, L.E., McCraren, J.P., Fowler, L.G Lconard, J.R. (1982). Fish Hatchery Management. U.S. Fish and Wildlife Service, Washington, DC.

Poxton, M.G., Murray, K.R. and Linfoot, B.T. (1982). The growth of turbot (Scophalmus maximus) in recirculating systems. Aquacultral Engineering, 1:23-34.

Rakocy, J.E. (1989). Tank culture of tilapia. In the biology and culture of tilapia, ed. R. S. V. Pullin \& R. H. Lowe-McConell-ICLARM conference proceedings 7 . International center for living aquatic resources management, manila, the Philippines.

Rodrigo, A.L. and Olivares J.F. (2004). Culture of turbot (Scopphthalmus maximus) juveniles using shallow raceways tanks and recirculation. Aquacultural Engineering, 32:113-127.

Ross, R.M., Watten, B.J., Krise, W.F. and Dilauro, M.N. (1995). Influence of tank design and hydraulic loading on the behaviour, growth, and metabolism of rainbow trout (Oncorhynchus mykiss). Aquaculture Engineering, 14:29-47.

Timmons, M.B., Summerfelt, S.T. and Vinci, B.J. (1998). Review of circular tank technology and managment. Aquacultural Engineering, 18:51-69. 
Timmons, M.B., Ebeling, J.M., Wheaton, F.W., Summerfelt, S.T. and Vinci, B.J. (2010). Recirculating Aquaculture Systems, 2nd Edition. Cayuga Aqua Ventures, Ithaca, NY 14850, USA. 939 p. NRAC Publication No. 401-2010.

Wheaton, F.W. (1977). Aquacultural Engineering, Wiley, New York.

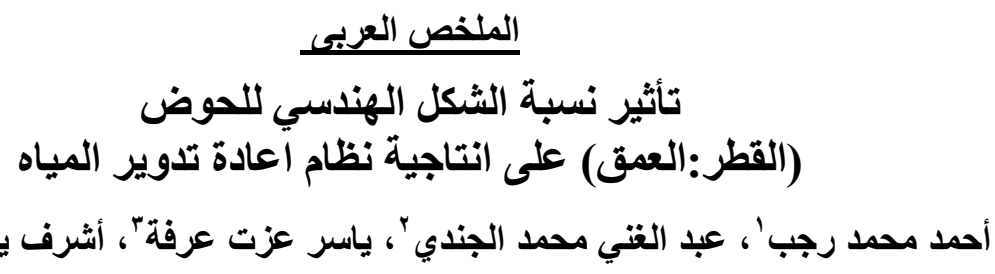

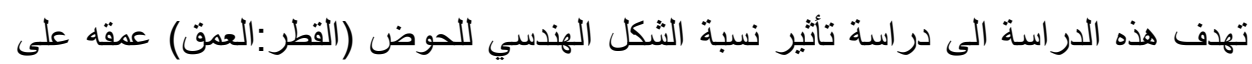

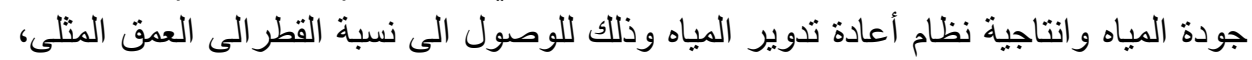
وكانت اهم النتائج المتحصل عليها كلئ كمايلى:-

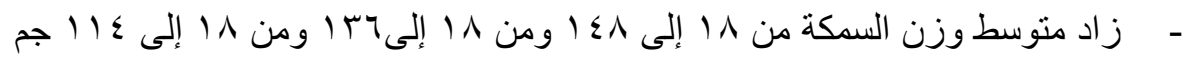

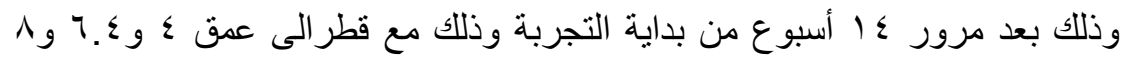
على الترتيب.

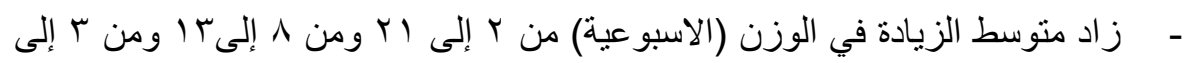

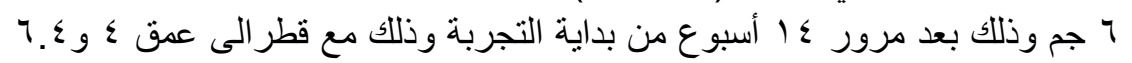
و إن على الترتيب.

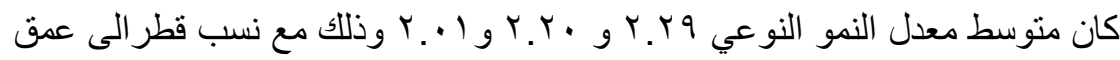

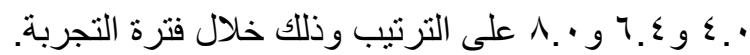

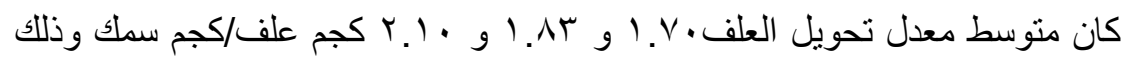

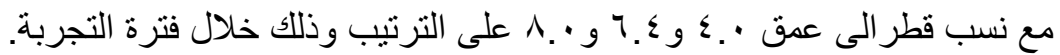

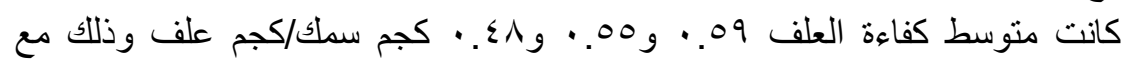

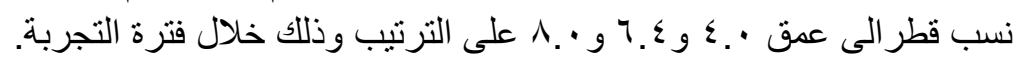

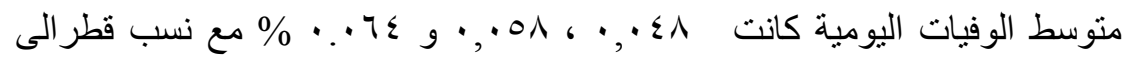

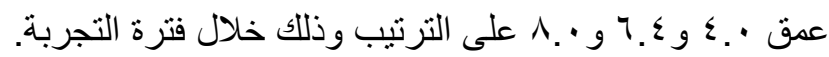

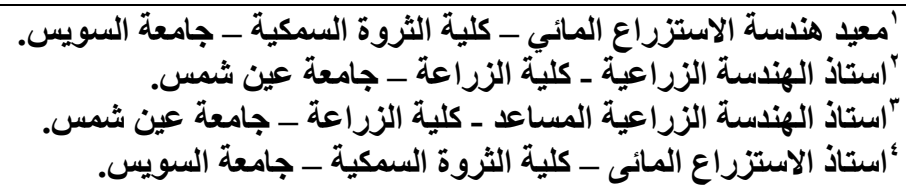

Misr J. Ag. Eng., July 2016 